\title{
Article \\ Predictors of Threat from COVID-19: A Cross-Sectional Study in the Spanish Population
}

\author{
María del Carmen Pérez-Fuentes ${ }^{1, * \mathbb{C}}$, Iván Herrera-Peco ${ }^{2,3, * \mathbb{C}}$, María del Mar Molero Jurado $1, * \mathbb{(}$, \\ Nieves Fátima Oropesa ${ }^{1}\left[\right.$ and José Jesús Gázquez Linares ${ }^{4, *}$ \\ 1 Department of Psychology, Faculty of Psychology, University of Almería, 04120 Almería, Spain; \\ foropesa@ual.es \\ 2 Nursing Department, Faculty of Health Sciences, Alfonso X El Sabio University, 28691 Madrid, Spain \\ Alfonso X El Sabio Foundation, 28691 Madrid, Spain \\ 4 Department of Psychology, Universidad Autónoma de Chile, Providencia 7500000, Chile \\ * Correspondence: mpf421@ual.es (M.d.C.P.-F.); iherrpec@uax.es (I.H.-P.); mmj130@ual.es (M.d.M.M.J.); \\ jlinares@ual.es (J.J.G.L.)
}

Citation: Pérez-Fuentes, M.d.C.; Herrera-Peco, I.; Jurado, M.d.M.M.; Oropesa, N.F.; Gázquez Linares, J.J. Predictors of Threat from COVID-19: A Cross-Sectional Study in the Spanish Population. J. Clin. Med. 2021, 10, 692. https://doi.org/ $10.3390 /$ jcm10040692

Academic Editor: Michele Roccella Received: 12 January 2021

Accepted: 4 February 2021

Published: 10 February 2021

Publisher's Note: MDPI stays neutral with regard to jurisdictional claims in published maps and institutional affiliations.

Copyright: (c) 2021 by the authors. Licensee MDPI, Basel, Switzerland. This article is an open access article distributed under the terms and conditions of the Creative Commons Attribution (CC BY) license (https:/ / creativecommons.org/licenses/by/ $4.0 /)$.

\begin{abstract}
One of the first measures for fighting the worldwide spread of the COVID-19 pandemic is social isolation or quarantine. The perceived threat from COVID-19 in this situation, maintained over time, generates uncertainty and fears, etc., which could lead to mental disorders in the population. This study evaluated the perceived threat from COVID-19 in the Spanish population. The study design was cross-sectional and observational. The sample of 1014 participants recruited in Spain had a mean age of $40.87(S D=12.42)$. The gender distribution was $67.2 \%(n=681)$ women and $32.8 \%$ $(n=333)$ men. Data were collected with an online survey. The instrument used was the Perception of Threat from COVID-19 Questionnaire, validated for the Spanish population. Our data showed a clear correlation between perceived threat with female gender, having children in one's care and level of education. However, no association was observed with age or marital status. Finally, we concluded that there is a greater perception of threat from COVID-19 by women with a lower education who have children in their care, and that they are also more sensitive to minor mental disorders, such as anxiety or stress, appearing.
\end{abstract}

Keywords: coronavirus; COVID-19; public mental health; quarantine

\section{Introduction}

When pneumonia was detected in December 2019 in Wuhan, Hubei Province, China, its origin was unknown. However, by the beginning of January 2020, it was identified as the novel SARS-CoV-2 virus which causes the disease known as COVID-19 [1-3]. Its course goes through a series of systemic physical symptoms, such as fever, cough, fatigue, headache and diarrhea, and also respiratory affections that could include rhinorrhea, pneumonia or acute respiratory distress syndrome [3-5].

COVID-19 characteristics facilitated its rapid expansion, leading the World Health Organization to define it as a global pandemic on 31 January 2020 [6]. Its incubation period is about 5.2 days [7], with symptoms appearing in an average of 14 days [8]. In addition, a high percentage of virus carriers are asymptomatic, but they are nevertheless infective and can infect others if not detected in time [9], which, along with the enormous stream of transportation, could amplify its spread $[10,11]$ and the danger it represents to public health [12].

Due to the spread of the virus and the disease it causes, as well as the inexistence at the present time of effective treatments or vaccination against SARS-CoV-2 [13,14], a number of measures have been taken to reduce its spread and protect the population. These may be grouped in two main measures: limiting movement of the population and home confinement $[15,16]$. These measures, in addition to the pandemic itself, can have 
effects, not only on particular individuals but also on the physical and mental health of the entire population [17-22], and especially frontline professionals, such as healthcare workers $[23,24]$. With respect to the COVID-19 disease itself, as described in other infectious disease epidemics [25-28], some people have negative emotions causing behavior and attitudes that cause them to avoid contact with disease [29]. This defensive reaction to perceived threat from the disease can cause severe psychological maladjustments such as stress, depression and anxiety $[17,20,26,30]$.

The confinement due to the COVID-19 pandemic has been described by some authors as a possible cause of collective hysteria [31-33], a situation which, if it worsens and measures are hardened to mass quarantine, could generate anxiety [18]. It has been observed that people subjected to isolation may experience feelings of loneliness and anger in addition to problems in relating to others person-to-person and even in group social relations when isolation ends $[33,34]$.

The unpredictability of information received from authorities on control of the disease or severity of risk of contagion, and disinformation from both traditional communication media $[18,35]$ and on social networks such as Twitter, YouTube, Instagram or Facebook, among others [36-38] combine with the situation above, generating stress, fear, guilt, displeasure $[18,34,35,38]$ and so forth. Although they may not be considered mental illnesses in themselves, they can lead to situations compromising mental health [35]. Therefore, one's perception of the disease depends on the interpretation of experiences, how that interpretation is transferred to active behavior, the response to social reactions and the personal meaning attributed to the experience [39]. In the situation of imminent alarm in which society around the world now finds itself with COVID-19 and its effect on health $[16,17,24]$, the perception adults have of the disease as government measures change their habits, becomes very important. Perhaps one of the most significant changes is in the care of children or other dependents [40], as women, who traditionally care for the most vulnerable members of the family [41-43], could find their situation worsened under conditions such as those generated by the current pandemic.

The significant role of healthcare professionals as guarantors of both physical and mental health of the population [44], even in situations of public health conflict [45] should also be mentioned. At the present time, there is not much information on the psychological impact and mental health of the general population [6]. A large number of scientific publications have focused on analysis and identification of epidemiological and clinical characteristics of infected patients, genome identification and morphology of the virus and situations related to the logistics and political and healthcare policy decisionmaking $[5,32,46]$. The the psychological state of the Spanish population has not yet been defined, although there are such studies on specific groups in the Spanish population, like nurses [47] or university students [48].

The objective of this study was to explore the threat perceived by Spanish society from the lockdown imposed because of the COVID-19 epidemic. We think that uncertainty and lack of information about COVID-19 could affect cognitive and emotional health [7]. An evaluation of perceived threat by COVID-19 [39] that would provide information on which groups are the most sensitive to the pernicious effects on mental health of both COVID-19 and the measures taken to slow down its contagion would be useful for healthcare authorities as well as primary care professionals in attending patients.

\section{Method}

\subsection{Participants}

The study sample was made up of a total of 1043 Spanish adults residing in 19 autonomous regions of which Andalusia was most represented with $37.9 \%$ of the participants, followed by Madrid with $27.5 \%$. Of these 29 were eliminated because of random or incongruent answers on control questions included in the questionnaire, leaving 1014 participants in the study. 
Ethical research standards were complied with, providing information on the project and requesting consent to participate. The study was approved by the University of Almería Bioethics Committee.

\subsection{Design and Data Collection}

A cross-sectional observational study planned was carried out as an online survey due to the state of emergency decreed in Spain last 14 March and the restriction of movement, making a person-to-person format impossible.

The sample was acquired by snowball sampling by spreading the link to the questionnaire on social networking sites. Data was acquired from 18 March through 23 March 2020.

\subsection{Instruments and Variables}

This study used the Perception of Threat from COVID-19 Questionnaire validated for an adult Spanish population [39]. The questionnaire consists of five items focused on the perception of threat from COVID-19 (Table 1), where the participants rate their agreement with the statements on a Likert-type scale of 0 to 10. The test offers an overall score on the representation of the disease, where the highest scores indicate greater perception of COVID-19 as a threat. This questionnaire showed acceptable internal consistency $(\alpha=0.66)$.

Table 1. Items measured by the Perception of Threat from COVID-19 instrument (by author).

\begin{tabular}{lccc}
\hline \multicolumn{1}{c}{ Items } & Range & M & SD \\
\hline How much is coronavirus infection affecting your life? & $1-10$ & 7.62 & 2.13 \\
\hline How long do you think the coronavirus infection alert will last? & $1-10$ & 6.84 & 1.60 \\
\hline To what extent do you feel symptoms due to infection by coronavirus? & $1-10$ & 2.03 & 1.85 \\
\hline How much are you worried about infection by coronavirus? & $1-10$ & 7.65 \\
\hline $\begin{array}{l}\text { How much are you affected emotionally by infection by coronavirus? (That is, do you } \\
\text { feel furious, afraid, angry, depressed?) }\end{array}$ & \multirow{2}{*}{$1-10$} & 6.58 \\
\hline
\end{tabular}

In addition, an ad hoc questionnaire on the following socio descriptive variables was included: Gender (man or woman), age, marital status (married, single, widowed or divorced), education (no education, primary school, high school and higher education), autonomous region, "Do you have any minor children?" (yes, no), "Is anyone close to you COVID-19 positive?" (yes, no).

\subsection{Data Analysis}

First, relative and absolute frequencies were calculated in a descriptive analysis of the sociodemographic variables.

Then, relationships between the quantitative variables were explored by correlation analysis, and categorical variables by Student's $t$-test and ANOVA. In the hypothesis comparisons, 0.05 was considered statistical significance and the confidence intervals were calculated at $95 \%$.

After that, a binary logistic regression was performed using the enter method. The dependent variable for this was perceived threat, previously dichotomized into mediumlow/medium high. The predictor variables, based on the results of preliminary analyses, were sex, having minor children in one's care and education.

SPSS version 23.0 for Windows was used for data processing and analysis.

\section{Results}

\subsection{Descriptive Analysis}

The mean age was $40.87(\mathrm{SD}=12.42)$ in a range of 18 to 76 . The gender distribution was $67.2 \%(n=681)$ women and $32.8 \%(n=333)$ men, with a mean age of $39.88(S D=12.35)$ 
and $42.92(\mathrm{SD}=12.33)$, respectively. Over $90 \%$ of the sample was single $(30.9 \%)$ or married $(60.1 \%)$. Over $90 \%$ had a secondary or higher education (16\% and $78.7 \%$, respectively). When asked if they had minor children, 35.9\% (364) answered affirmatively (see Table 2). And finally, only $16.4 \%(n=166)$ had someone COVID-19 positive close to them.

Table 2. Sociodemographic characteristics of the participants.

\begin{tabular}{ccc}
\hline Variables & $\%$ & $\mathbf{n}$ \\
\hline Sex & & 333 \\
Men & $32.8 \%$ & 681 \\
Women & $67.2 \%$ & \\
Marital status & & 313 \\
Single & $30.9 \%$ & 609 \\
Married & $60.1 \%$ & 82 \\
Divorced & $8.1 \%$ & 10 \\
Widowed & $1 \%$ & \\
Education & & 3 \\
No education & $0.3 \%$ & 162 \\
Primary school & $5 \%$ & 798 \\
High school & $16 \%$ & \\
Higher education & $78.7 \%$ & 650 \\
\hline No & & 364 \\
\hline Yes & $64.1 \%$ & 848 \\
Do you have any minor children? & $35.9 \%$ & 166 \\
\hline No & & \\
\hline Ys anyone close to you COVID-19 positive? & $82.6 \%$ & $16.4 \%$ \\
\hline
\end{tabular}

Potential explanatory variables were selected by descriptive analysis of their relationships with perceived threat. The quantitative variables were examined with bivariate correlations, in which no correlation with perceived threat was found for age: $r=0.05, p=0.092$, $95 \%$ CI (-0.009; 0.114). Education, coded on a scale in ascending order from $0=$ "no education" to $3=$ "higher education", correlated negatively to perceived threat: $r=-0.08$, $p<0.01 ; 95 \%$ CI $(-0.149 ;-0.027)$. No statistically significant between-group differences were observed by marital status $(F=2.03 ; p=0.108)$ in the analysis of perceived threat.

However, differences were detected (t1012 $=-5.15 ; p<0,001 ; \mathrm{d}=0.34)$ by gender (Figure 1a), in which women perceived higher threat $(\mathrm{M}=31.47$; $\mathrm{SD}=6.29)$ than men $(\mathrm{M}=29.21$; $\mathrm{SD}=7.03)$. Furthermore, those with minor children in their care $(\mathrm{M}=31.50$; $\mathrm{SD}=6.63)$ differed significantly $(\mathrm{t} 1012=-2.77 ; p<0,01 ; \mathrm{d}=0.18)$ from those who did not $(M=30.30 ; S D=6.59)$, where the first scored higher in perceived threat from COVID-19 (Figure 1b).

\subsection{Logistic Regression Model}

Based on the above descriptive analyses, the independent variables entered in the logistic regression model for predicting perceived threat were gender, having minor children and education. In this case, the total score for the variable on the questionnaire was previously dichotomized by visual grouping and percentiles based on the cases explored.

The cutoff point was set at 31.5, forming two intervals or groups, one medium-low threat with scores equal to or lower, and medium-high threat, with higher scores. Later recording of the variable (once the cutoff points had been found by visual grouping) was done manually.

Table 3 shows the results of the logistic regression analysis: regression coefficients, standard error of the estimate, Wald statistic, degrees of freedom and associated probability, partial correlation coefficient and cross-product. 


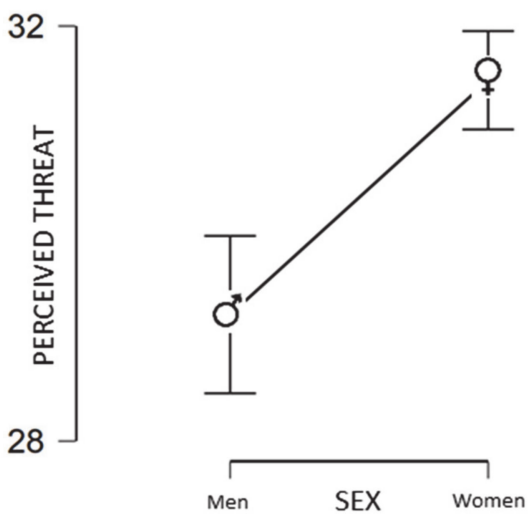

(a)

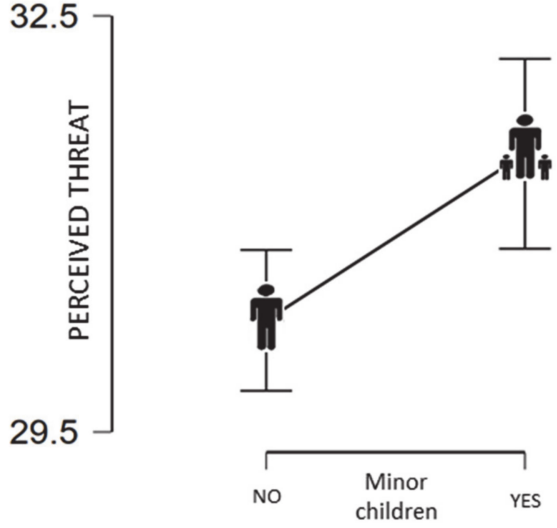

(b)

Figure 1. (a) Perceived threat by gender. (b) Perceived threat by whether there were minor children in their care.

Table 3. Results derived from the logistic regression for probability of perceived threat.

\begin{tabular}{cccccccc}
\hline Variables & $\boldsymbol{\beta}$ & St. Error & Wald & df & Sig. & Exp( $\beta$ ) & CI 95\% \\
\hline Sex (a) & 0.633 & 0.137 & 21.224 & 1 & 0.000 & 1.884 & $1.439-2.467$ \\
Minor children (b) & 0.355 & 0.134 & 6.980 & 1 & 0.008 & 1.426 & $1.096-1.857$ \\
Education & -0.261 & 0.116 & 5.031 & 1 & 0.025 & 0.770 & $0.613-0.968$ \\
Constant & 0.159 & 0.341 & 0.217 & 1 & 0.641 & 1.172 & \\
\hline
\end{tabular}

Note. (a) Women; (b) With minors in their care.

The odds ratio found for each variable indicates that risk of perceiving strong threat is higher among women with minor children in their care and with low education.

Overall fit of the model $\left(\chi^{2}=32.57 ; \mathrm{df}=3 ; p<0.001\right)$, was confirmed by HosmerLemeshow test $\left(\chi^{2}=1.54 ; \mathrm{df}=5 ; p=0.908\right)$. In addition, the Nagelkerke R2 indicated that $4.2 \%$ of the variability in the response variable would be explained by the logistic regression model.

\section{Discussion}

The novel results of this study found possible psychological problems related to perceived threat from the infectious disease COVID-19.

In the first place, analysis of the threat perceived by the population showed that neither participant age nor marital status influenced perception of threat. However, gender did influence that perception. It was observed that women were particularly more prone to perceive the COVID-19 disease as a threat. This might be attributed to a woman's traditional role in society as planner and caregiver of the family unit [41-43], related to a feeling of moral and affective obligation [40]. Although men have become more involved with childcare since the economic crisis of 2008, or when they are unemployed, it seems that this trend is not maintained when they are employed, devoting less time to caring for children than mothers [40]. This is not the case of women, who care for the family regardless of whether they are otherwise employed.

Another factor found to be positively related to perception of threat was having children in one's care, which could be associated with fear that the children would be infected by the disease or even lost $[23,28,49]$.

A lower level of education was associated with perceived threat from COVID-19, perhaps related to access to sources of information and to understanding based on previous knowledge $[47,48,50]$. Thus, a higher level of education would be associated with a greater critical capacity of information consumed and processed and the tendency to seek other sources of information to corroborate or refute information acquired [51]. 
It is worth mentioning that information sources, whether communication media or social networking sites, may generate uncertainty $[18,35,36,38]$ because of the way the news is explained, providing incoherent data which could generate anxiety or fear in an epidemic, or by way of "false experts" who generate biased and erroneous interpretations of data, causing confusion and unease.

A clear example that social networks can generate a high percentage of untrustworthy information if one does not know how to filter it is YouTube, where during the Zika pandemic, it was found that $25 \%$ of the videos published on that subject contained unreliable and biased information [38]. This was also true during the Ebola pandemic, where 63.5\% of the videos analyzed contained unreliable information [37], and also at other social networking sites [36]. This situation of uncertainty due to access to unclear and even biased information can generate a high level of uncertainty associated in turn with anxiety and depressive symptoms [20].

In addition, it was found that women without an education and with minor children in their care had a stronger feeling of threat from COVID-19. This could explain the association in the sample studied, as they did not have enough knowledge to enable them to filter information received from the communication media or social networks, thus generating anxiety and stress, a normal response of fear and protection for loved ones [19,49] in the traditional caregiver role of women [40,42,43].

Even though the COVID-19 pandemic is considered a public health emergency [12] understood as a binomial made up of physical and mental health [21], it should be highlighted that there are no studies on the analysis of threat perceived by the population and the possible importance of this perception on development of alterations in mental health during crisis situations, such as the COVID-19 pandemic. In this regard, the increase in minor mental disorders in the Spanish population during the economic crisis of 2008 should be emphasized [44]. This situation and experiences in countries where the fight against the disease has been longer, such as China, makes intervention for possible psychological affectation necessary in the population as a public health response [18,22,25].

In spite of the contributions made in this study, it is important to emphasize its limitations. The study sample, due to the nonprobability sampling used, was not representative. In this respect, it should be mentioned that a high percentage of participants were women, and that most of the participants had a higher education, which also affects the representativeness of the results. Moreover, there may have been social desirability biases associated with the self-reports used for data collection. Lastly, (although it might not be considered a real limitation, it should be noted that) due to the sudden occurrence of the pandemic, we were unable to assess the mental health burden in a Spanish population beforehand. Therefore, future research should improve the sampling technique to avoid possible biases.

Finally, while our original research goal was to analyze the perception of the threat associated with the COVID-19 pandemic and control strategies for reducing the spread of the virus, we realize that previous studies have also been done in countries like Italy [52], Greece [53] or Canada [54] that suggest a relationship between the COVID-19 pandemic and control strategies, with the appearance of anxiety and depression disorders in these populations. Therefore as a future line of research, we will delve more deeply into the relationship of anxiety and depression to the Spanish population's mental health during the COVID-19 pandemic.

\section{Conclusions}

In conclusion, the results of this study show that in a situation such as the one we are now experiencing, there is a feeling of threat from COVID-19, which is worsened by isolation during lockdown. Some groups in the sample had a greater perception of threat, especially women with lower education who have children in their care, and they were more sensitive to minor mental disorders appearing, such as anxiety or stress.

We believe this situation may be similar to past economic crises which have caused a significant increase in burnout [54] and mental disorders in Spain. Therefore, healthcare 
authorities should evaluate the implementation of policies directed at providing the material and human resources for healthcare professional teams in community care, so these professionals can detect and act quickly against any minor mental health disorder derived from the stress and fear from perceived threat of COVID-19 and daily abnormal situations through community activities and even educational intervention.

Author Contributions: M.d.C.P.-F. contributed to the concept, design, and analysis and interpretation of the data. I.H.-P. contributed to collecting the data, to the concept and design, and manuscript preparation. M.d.M.M.J. contributed to the concept, design, and analysis and interpretation of the data. N.F.O. contributed to the technical details and manuscript preparation. J.J.G.L. contributed to critically revising the manuscript for important intellectual content and the final approval of the version to be published. All authors have read and agreed to the published version of the manuscript.

Funding: This research received no external funding.

Institutional Review Board Statement: The study was conducted according to the guidelines of the Declaration of Helsinki, and approved by the Ethics Committee of University of Almería (protocol code UALBIO2020/021 25/06/2020).

Informed Consent Statement: Informed consent was obtained from all subjects involved in the study.

Data Availability Statement: The data presented in this study are available on request from the corresponding author.

Acknowledgments: The present study was undertaken in collaboration with Excma. Diputación Provincial.

Conflicts of Interest: The authors declare no conflict of interest.

\section{References}

1. Lai, C.C.; Shih, T.P.; Ko, W.C.; Tang, H.J.; Hsueh, P.R. Severe acute respiratory syndrome coronavirus 2 (SARS-CoV-2) and coronavirus disease-2019 (COVID-19): The epidemic and the challenges. Int. J. Antimicrob. Agents 2020, 55, 105924. [CrossRef]

2. Rodríguez-Morales, A.J.; MacGregor, K.; Kanagarajah, S.; Patel, D.; Schlagenhauf, P. Going global-Travel and the 2019 novel coronavirus. Travel Med. Infect. Dis. 2020, 33, 101578. [CrossRef]

3. Rothan, H.A.; Byrareddy, S.N. The epidemiology and pathogenesis of coronavirus disease (COVID-19) outbreak. J. Autoimmun. 2020, 109, 102433. [CrossRef]

4. Lake, A.M. What we know so far: COVID-19 current clinical knowledge and research. Clin. Med. 2020, 20, 124-127. [CrossRef] [PubMed]

5. Chen, N.; Zhou, M.; Dong, X.; Qu, J.; Gong, F.; Han, Y.; Qiu, Y.; Wang, J.; Liu, Y.; Wei, Y.; et al. Epidemiological and clinical characteristics of 99 cases of 2019 novel coronavirus pneumonia in Wuhan, China: A descriptive study. Lancet 2020, 395, 507-513. [CrossRef]

6. Wang, F.-S.; Zhang, C. What to do next to control the 2019-nCoV epidemic? Lancet 2020, 395, 391-393. [CrossRef]

7. Li, Q.; Guan, X.; Wu, P.; Wang, X.; Zhou, L.; Tong, Y.; Ren, R.; Leung, K.S.M.; Lau, E.H.Y.; Wong, J.Y.; et al. Early transmission dynamics in Wuhan, China, of Novel Coronavirus-infected pneumonia. N. Engl. J. Med. 2020, 382, 1199-1207. [CrossRef] [PubMed]

8. Wang, W.; Tang, J.; Wei, F. Updated understanding of the outbreak of 2019 novel coronavirus (2019-nCoV) in Wuhan, China. J. Med. Virol. 2020, 92, 441-447. [CrossRef] [PubMed]

9. Rothe, C.; Schunk, M.; Seilmaier, M.; Drosten, C.; Vollmar, P.; Zwirglmaier, K.; Zange, S.; Wölfel, R.; Hoelscher, M.; Sothmann, P.; et al. Transmission of 2019-nCoV infection from an asymptomatic contact in Germany. N. Engl. J. Med. 2020, 382, 970-971. [CrossRef]

10. Balcan, D.; Gonçalves, B.; Hu, H.; Ramasco, J.J.; Colizza, V.; Vespignani, A. Modeling the spatial spread of infectious diseases: The gLobal Epidemic and mobility computational model. J. Comput. Sci. 2010, 1, 132-145. [CrossRef]

11. Chinazzi, M.; Davis, J.T.; Ajelli, M.; Gioannini, C.; Litvinova, M.; Merler, S.; Piontti, A.P.Y.; Mu, K.; Rossi, L.; Sun, K.; et al. The effect of travel restrictions on the spread of the 2019 novel coronavirus (COVID-19) outbreak. Science 2020, 368, 395-400. [CrossRef]

12. Cruz, M.P.; Santos, E.; Cervantes, M.V.; Juárez, M.L. COVID-19, una emergencia de salud pública mundial. Rev. Clín. Esp. 2021, 221, 55-61. [CrossRef] [PubMed]

13. Abdelhafiz, A.S.; Mohammed, Z.; Ibrahim, M.E.; Ziady, H.H.; Alorabi, M.; Ayyad, M.; Sultan, E.A. Knowledge, perceptions, and attitude of egyptians towards the novel coronavirus disease (Covid-19). J. Commun. Health 2020, 45, 881-890. [CrossRef]

14. Li, J.-Y.; You, Z.; Wang, Q.; Zhou, Z.-J.; Qiu, Y.; Luo, R.; Ge, X.-Y. The epidemic of 2019-novel-coronavirus (2019-nCoV) pneumonia and insights for emerging infectious diseases in the future. Microbes Infect. 2020, 22, 80-85. [CrossRef] [PubMed] 
15. Lau, H.; Khosrawipour, V.; Kocbach, P.; Mikolajczyk, A.; Schubert, J.; Bania, J.; Khosrawipour, T. The positive impact of lockdown in Wuhan on containing the COVID-19 outbreak in China. J. Travel Med. 2020, 27, taaa037. [CrossRef] [PubMed]

16. Zhu, W.; Li, X.; Wu, Y.; Xu, C.; Li, L.; Yang, J.; Fang, S. Community quarantine strategy against coronavirus disease 2019 in Anhui: An evaluation based on trauma center patients. Int. J. Infect. Dis. 2020, 96, 417-421. [CrossRef]

17. Ho, C.S.; Chee, C.Y.; Ho, R.C. Mental health strategies to combat the psychological impact of COVID-19 beyond paranoia and panic. Ann. Acad. Med. Singap. 2020, 49, 1-3.

18. Rubin, G.J.; Wessely, S. The psychological effects of quarantining a city. BMJ 2020, 368, m313. [CrossRef]

19. Berggren, N.; Curtis, H.; Derakshan, N. Interactions of emotion and anxiety on visual working memory performance. Psychon. Bull. Rev. 2016, 24, 1274-1281. [CrossRef]

20. Dar, K.A.; Iqbal, N.; Mushtaq, A. Intolerance of uncertainty, depression, and anxiety: Examining the indirect and moderating effects of worry. Asian J. Psychiatry 2017, 29, 129-133. [CrossRef]

21. Ohrnberger, J.; Fichera, E.; Sutton, M. The relationship between physical and mental health: A mediation analysis. Soc. Sci. Med. 2017, 195, 42-49. [CrossRef] [PubMed]

22. Dong, L.; Bouey, J. Public mental health crisis during COVID-19 pandemic, China. Emerg. Infect. Dis. 2020, 26, 1616-1618. [CrossRef] [PubMed]

23. Hernández, B.C.; Rugarcía, Y.T. Attitudes toward the risk prevention in health professionals in cases of epidemiological alert. Med. Segur. Trab. 2015, 61, 254-272.

24. Greenberg, N.; Docherty, M.; Gnanapragasam, S.; Wessely, S. Managing mental health challenges faced by healthcare workers during covid-19 pandemic. BMJ 2020, 368, m1211. [CrossRef]

25. Tucci, V.; Moukaddam, N.; Meadows, J.; Shah, S.; Galwankar, S.C.; Kapur, G.B. The forgotten plague: Psychiatric manifestations of ebola, zika, and emerging infectious diseases. J. Glob. Infect. Dis. 2017, 9, 151-156. [CrossRef]

26. Lai, J.; Ma, S.; Tan, H.; Kang, L.; Yao, L.; Huang, M.; Wang, H.; Wang, G.; Liu, Z.; Hu, S.; et al. Factors associated with mental health outcomes among health care workers exposed to coronavirus disease 2019. JAMA Netw. Open 2020, 3, e203976. [CrossRef]

27. Cosic, K.; Popovic, S.; Sarlija, M.; Kesedzic, I. Impact of human disasters and COVID-19 pandemic on mental health: Potential of digital psychiatry. Psychiatr. Danub. 2020, 32, 25-31. [CrossRef]

28. Maunder, R.; Hunter, J.; Vincent, L.; Bennett, J.; Peladeau, N.; Leszcz, M.; Sadavoy, J.; Verhaeghe, L.M.; Steinberg, R.; Mazzulli, T. The immediate psychological and occupational impact of the 2003 SARS outbreak in a teaching hospital. CMAJ 2003, 168, 1245-1251.

29. Li, S.; Wang, Y.; Xue, J.; Zhao, N.; Zhu, T. The impact of COVID-19 epidemic declaration on psychological consequences: A study on active weibo users. Int. J. Environ. Res. Public Health 2020, 17, 2032. [CrossRef]

30. Broadbent, E.; Wilkes, C.; Koschwanez, H.; Weinman, J.; Norton, S.; Petrie, K.J. A systematic review and meta-analysis of the Brief Illness Perception Questionnaire. Psychol. Health 2015, 30, 1361-1385. [CrossRef] [PubMed]

31. Barbisch, D.; Koenig, K.L.; Shih, F.-Y. Is there a case for quarantine? Perspectives from SARS to Ebola. Disaster Med. Public Health Prep. 2015, 9, 547-553. [CrossRef] [PubMed]

32. Wang, C.; Pan, R.; Wan, X.; Tan, Y.; Xu, L.; Ho, C.; Ho, R. Immediate psychological responses and associated factors during the initial stage of the 2019 coronavirus disease (Covid-19) Epidemic among the general population in China. Int. J. Environ. Res. Public Health 2020, 17, 1729. [CrossRef]

33. Xiang, Y.-T.; Yang, Y.; Li, W.; Zhang, L.; Zhang, Q.; Cheung, T.; Ng, C.H. Timely mental health care for the 2019 novel coronavirus outbreak is urgently needed. Lancet Psychiatry 2020, 7, 228-229. [CrossRef]

34. Zhang, J.; Wu, W.; Zhao, X.; Zhang, W. Recommended psychological crisis intervention response to the 2019 novel coronavirus pneumonia outbreak in China: A model of West China Hospital. Precis. Clin. Med. 2020, 3, 3-8. [CrossRef]

35. Bao, Y.; Sun, Y.; Meng, S.; Shi, J.; Lu, L. 2019-nCoV epidemic: Address mental health care to empower society. Lancet 2020, 395, e37-e38. [CrossRef]

36. Gao, J.; Zheng, P.; Jia, Y.; Chen, H.; Mao, Y.; Chen, S.; Wang, Y.; Fu, H.; Dai, J. Mental health problems and social media exposure during COVID-19 outbreak. PLoS ONE 2020, 15, e0231924. [CrossRef]

37. Fung, I.C.-H.; Fu, K.-W.; Chan, C.-H.; Chan, B.S.B.; Cheung, C.-N.; Abraham, T.; Tse, Z.T.H. Social media's initial reaction to information and misinformation on Ebola, August 2014: Facts and rumors. Public Health Rep. 2016, 131, 461-473. [CrossRef] [PubMed]

38. Bora, K.; Das, D.; Barman, B.; Borah, P. Are internet videos useful sources of information during global public health emergencies? A case study of YouTube videos during the 2015-16 Zika virus pandemic. Pathog. Glob. Health 2018, 112, 320-328. [CrossRef]

39. Pérez-Fuentes, M.D.C.; Molero Jurado, M.D.M.; Ruiz Oropesa, N.F.; Marto Martínez, Á.; Simon Márquez, M.D.M.; Herrera-Peco, I.; Gázquez Linares, J.J. Questionnaire on perception of threat from COVID-19. J. Clin. Med. 2020, 9, 1196. [CrossRef]

40. Calasanti, T.; King, N. Taking 'women's work' 'like a man': Husbands' experiences of care work. Gerontologist 2007, 47, 516-527. [CrossRef]

41. Guberman, M.N.; Maheu, M.P.; Maillé, C. Women as family caregivers: Why do they care? Gerontologist 1992, 32, 607-617. [CrossRef] [PubMed]

42. Benson, R.; Glaser, K.; Corna, L.M.; Platts, L.G.; Di Gessa, G.; Worts, D.; Price, D.; McDonough, P.; Sacker, A. Do work and family care histories predict health in older women? Eur. J. Public Health 2017, 27, 1010-1015. [CrossRef] 
43. Halper, L.R.; Cowgill, C.M.; Rios, K. Gender bias in caregiving professions: The role of perceived warmth. J. Appl. Soc. Psychol. 2019, 49, 549-562. [CrossRef]

44. Gómez, R.A.; Reina, L.L.; Méndez, I.F.; García, J.M.; Briñol, L.G. El psicólogo clínico en los centros de salud. Un trabajo conjunto entre atención primaria y salud mental. Atención Primaria 2019, 51,310-313. [CrossRef] [PubMed]

45. Gené-Badia, J.; Comice, P.; Belchín, A.; Erdozain, M. Ángeles; Cáliz, L.; Torres, S.; Rodríguez, R. Perfiles de soledad y aislamiento social en población urbana. Aten. Prim. 2020, 52, 224-232. [CrossRef]

46. Phan, T. Genetic diversity and evolution of SARS-CoV-2. Infect. Genet. Evol. 2020, 81, 104260. [CrossRef]

47. Blanco-Donoso, L.M.; Moreno-Jiménez, J.; Amutio, A.; Gallego-Alberto, L.; Moreno-Jiménez, B.; Garrosa, E. Stressors, job resources, fear of contagion, and secondary traumatic stress among nursing home workers in face of the COVID-19: The case of Spain. J. Appl. Gerontol. 2020. [CrossRef]

48. Martínez-Lorca, M.; Martínez-Lorca, A.; Criado-Álvarez, J.J.; Armesilla, M.D.C.; Latorre, J.M. The fear of COVID-19 scale: Validation in Spanish university students. Psychiatry Res. 2020, 293, 113350. [CrossRef] [PubMed]

49. Cuan-Baltazar, J.Y.; Muñoz-Perez, M.J.; Robledo-Vega, C.; Pérez-Zepeda, M.F.; Soto-Vega, E. Misinformation of COVID-19 on the internet: Infodemiology study. JMIR Public Health Surveill. 2020, 6, e18444. [CrossRef]

50. Singh, D.R.; Sunuwar, D.R.; Karki, K.; Ghimire, S.; Shrestha, N. Knowledge and perception towards universal safety precautions during early phase of the COVID-19 outbreak in Nepal. J. Community Health 2020, 45, 1116-1122. [CrossRef] [PubMed]

51. Epifanio, M.S.; Andrei, F.; Mancini, G.; Agostini, F.; Piombo, M.A.; Spicuzza, V.; Riolo, M.; Lavanco, G.; Trombini, E.; La Grutta, S. The impact of COVID-19 pandemic and lockdown measures on quality of life among Italian general population. J. Clin. Med. 2021, 10, 289. [CrossRef] [PubMed]

52. Skapinakis, P.; Bellos, S.; Oikonomou, A.; Dimitradis, G.; Gkikas, P.; Perdikari, E.; Mavreas, V. Depression and its relationship with copping strategies and illness perceptions during the COVID-19 lockdown in Greece: A croos-sectional survey of the population. Depress. Res. Treat. 2020, 2020, 3158954. [CrossRef] [PubMed]

53. Liu, S.; Lithopoulos, A.; Zhang, C.-Q.; Garcia-Barrera, M.A.; Rhodes, R.E. Personality and perceived stress during COVID-19 pandemic: Testing the mediating role of perceived threat and efficacy. Pers. Individ. Differ. 2021, 168, 110351. [CrossRef] [PubMed]

54. Pérez-Fuentes, M.D.C.; Molero-Jurado, M.D.M.; Gázquez-Linares, J.J.; Simón-Márquez, M.D.M. Analysis of Burnout Predictors in Nursing: Risk and Protective Psychological Factors. Eur. J. Psychol. Appl. Leg. Context 2019, 11, 33-40. [CrossRef] 